\title{
On The Durability of fine Grained Soils Stabilized With Lime
}

\author{
Dr. Suhail Adrees A. Khattab \\ Assistant Professor/Mosul University
}

\author{
Yousif Abduallah Hussein \\ Assistant Lecturer/Mosul University
}

\begin{abstract}
Measuring the durability of lime stabilized soils is one of the main concerns in soil stabilization, since there is no standard procedure for this case. This research studies the durability of lime stabilized fine grained soils using the slake durability device.

The effects of curing time and temperature, molding moisture contents, test duration time, and the effect of drying or wetting the samples before slaking, on the durability of gypseous soil (34\% gypsum) A and clayey soil B were studied. The results showed that the increase of molding moisture content decrease the weight loss for both soils, also it is found that soil A gave higher weight loss than soil B. Increasing the curing temperature or curing time decreases the loss weight due to pozzolanic reaction.

On the other hand, results indicated that the specimens wetted before slaking gave higher weight loss than specimens dried before slaking.

Finally, a linear relationship was obtained between test duration time and weight loss of soils. It is found that curing for 2 days at $25^{\circ} \mathrm{C}$ is approximately equivalent to curing for (4-13.5) days and (3.4-13.5) days at $25^{\circ} \mathrm{C}$ for soil $\mathrm{A}$ and $\mathrm{B}$ respectively.

Key words: durability, lime stabilization, slake durability, gypseous soils.

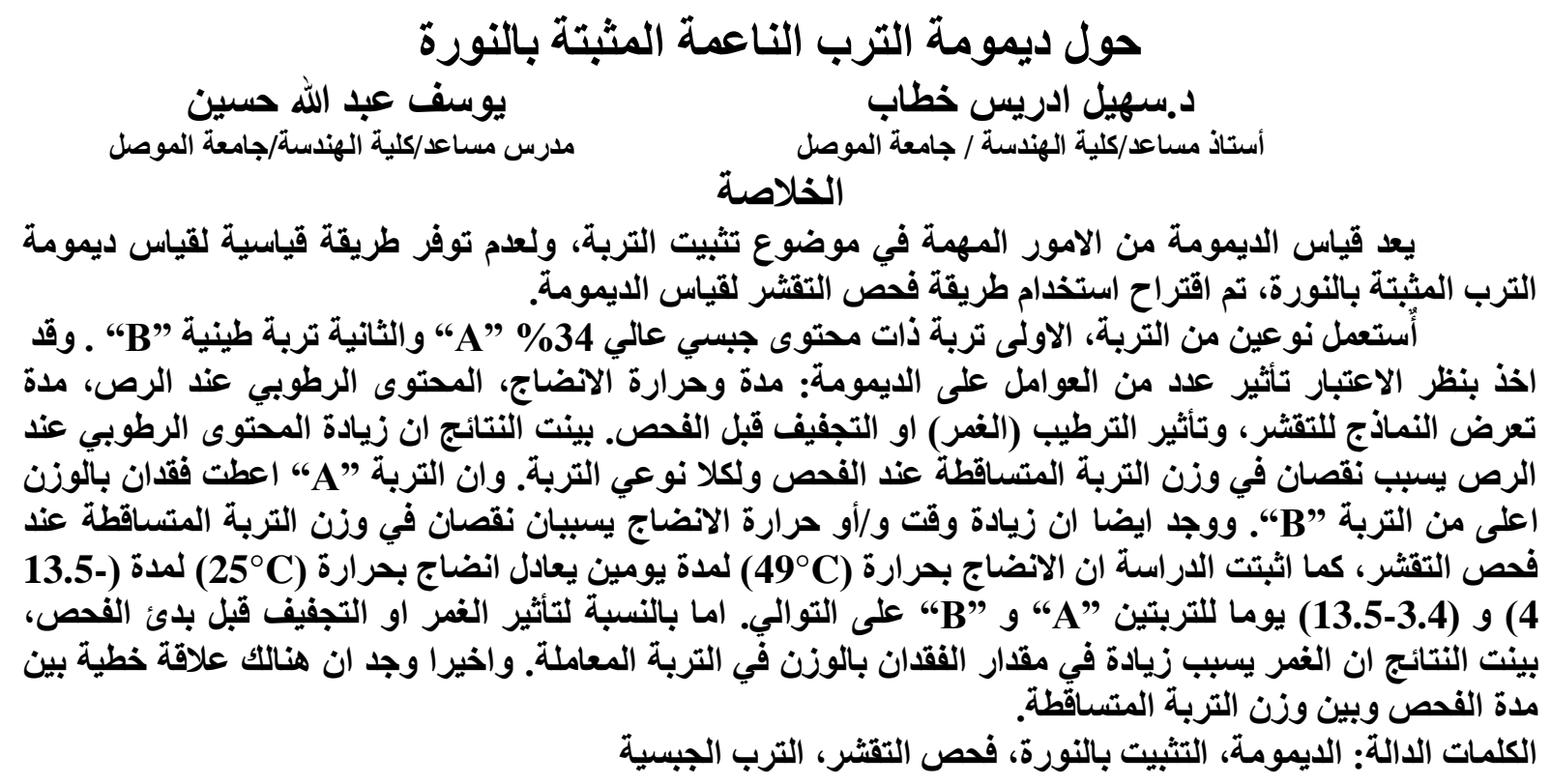

Received: $16-4-2010$

Accepted: $6-3-2011$ 


\section{1- Introduction:}

Durability is defined as the ability of stabilized soil to retain its strength, impermeability, and dimensional stability over prolonged period of service under the designed conditions. The degree of durability is based on the performance goals as defined by resistance to moisture absorption, strength reduction, and wetting and drying cycles [1].

For cement stabilized soils there are two standard procedures of durability tests. ASTM D559, Standard Test Method for Wetting and Drying of Compacted soil Cement Mixtures, and ASTM D560, Standard Test Method for Freezing and Thawing of Compacted soil Cement Mixtures [2].

For lime stabilized soils there is no standard procedure test, so different methods were used by different authors. Some researchers [3], [4], \& [5] used the brushing method described by the standard durability test ASTM D559, with some modifications. While others [3],[5],[6],\&[7] depended on the change of soil strength with wetting and drying test. Also the durability of lime stabilized soils was measured as the number of wetting and drying cycles that the soil samples could withstand without collapse [8]. Some researchers used the volume (or length) change of lime stabilized samples for durability measurement [3]. Also the durability was studied by measuring the unconfined compressive strength and the change of specimens length under loading and subjected to wetting and drying cycles[9]. While others studied the change of swelling characters of the lime stabilized soils with wetting and drying cycles, they found an increase in the soil-swelling with the increase of number of wetting and drying cycles [10] \& [11].

In the present research a new, quick and simple approach for measuring the durability of fine grained soils stabilized with lime is attempted, using the standard test method for slake durability of Shales and similar weak rocks, ASTM D4644 [2]. This method is originally used for measuring the durability of rocks or shales, Fig.(1) shows a diagram of the used test device.

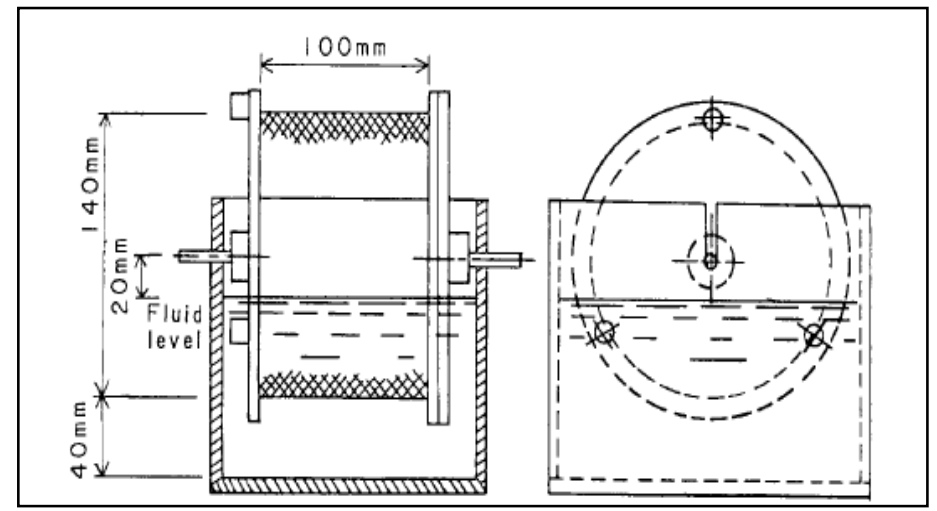

Fig.(1) Slake durability device (ASTM D4644)

\section{2- Materials and Methods:}

Two types of soils were selected for this study, gypseous and clayey soils, denoted as "A" and "B" respectively. The engineering properties of these soils are shown in the Table (1), also the compaction curves for soil A and B are shown in Fig.(1)

Table (1) Engineering properties of soil A and B

\begin{tabular}{|c|c|c|c|c|c|c|c|c|c|c|}
\hline \multirow{3}{*}{ Soil } & \multirow{3}{*}{ L.L. } & \multirow{3}{*}{ P.I. } & \multirow{3}{*}{ L.S } & \multirow{3}{*}{$\begin{array}{c}\text { Gypsum } \\
\%\end{array}$} & \multirow{3}{*}{ Gs } & \multicolumn{3}{|c|}{ Particles grain size } & \multirow{2}{*}{\multicolumn{2}{|c|}{$\begin{array}{l}\text { Compaction characteristics } \\
\text { Modified Proctor compaction }\end{array}$}} \\
\hline & & & & & & \multirow{2}{*}{$\begin{array}{c}\text { Sand } \\
(\%)\end{array}$} & \multirow{2}{*}{$\begin{array}{l}\text { Silt } \\
(\%)\end{array}$} & \multirow{2}{*}{$\begin{array}{l}\text { Clay } \\
(\%)\end{array}$} & & \\
\hline & & & & & & & & & $\gamma\left(\mathrm{kN} / \mathrm{m}^{3}\right)$ & o.m.c \\
\hline A & 26 & 6 & 5.1 & $34 \%$ & 2.52 & 22.5 & 53.5 & 24 & 17.62 & 15.2 \\
\hline $\mathrm{B}$ & 42 & 20 & 14.5 & $2 \%$ & 2.69 & 20 & 37 & 43 & 18 & 14 \\
\hline
\end{tabular}




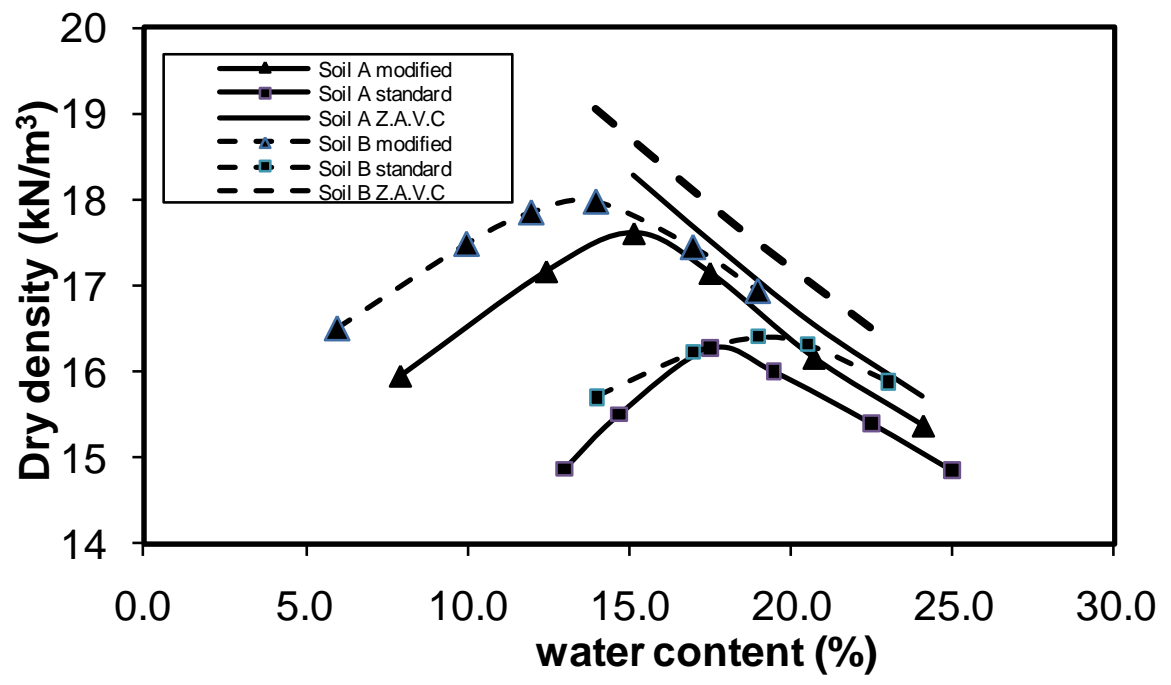

Fig.(1) Standard and modified Proctor compactive effort compaction curves for soil $A$ and $B$

Optimum lime content was selected according to Illinois procedure [12]; soil samples oven dried at $\left(60^{\circ} \mathrm{C}\right)$ and sieved on $\# 4(4.76 \mathrm{~mm})$ sieve, then mixed with different amount of lime. The mixture of soil and lime mixed with different water contents corresponding to compaction curve, warped in plastic sacks to prevent loss of moisture for 1 hour, then compacted with modified compactive effort in a mold of $5 \mathrm{~cm}$ diameter and $10 \mathrm{~cm}$ height, cured for 2 days at $49^{\circ} \mathrm{C}$. Finally the cured samples were tested for unconfined compressive strength, the optimum lime content for both soils is $4 \%$ as shown in the Tab.(2), which also shows the unit weight and the water content corresponding to the maximum unconfined compressive strength.

Table (2) Unconfined compressive Strength (U.C.S.) of Soil A \& B Stabilized With 4\% Lime

\begin{tabular}{|c|c|c|c|}
\hline Soil & U.C.S, $\left(\mathrm{kN} / \mathrm{m}^{2}\right)$ & Dry Density $\left(\mathrm{kN} / \mathrm{m}^{3}\right)$ & $\mathrm{w} / \mathrm{c}(\%)$ \\
\hline A & 2125 & 16.61 & 15.5 \\
\hline B & 4960 & 16.90 & 21.0 \\
\hline
\end{tabular}

\section{3- Preparation of Slake Durability Test Specimens:}

The mixtures were prepared with optimum lime content $4 \%$ and with three moisture contents; moisture content corresponding to the maximum unconfined compressive strength (which denoted as "omc" see Tab.(2)) and $\pm 5 \%$ the dry and wet sides of compaction curve (which denoted as "dry" \& "wet" respectively). After mellowing time for 1 hour, the soils were compacted with modified Proctor compactive effort in a mold of $3.5 \mathrm{~cm}$ diameter and $7.0 \mathrm{~cm}$ height the specimen extracted from the mold by means of a jack, the resultant mixture is of a cylindrical shape, of course, to get a spherical specimen the edges trimmed with a sharp knife until approximately spherical shape with (40-60)gm weight is obtained. The spherical specimen warped with foil paper then with wax to prevent loss of any moisture during the next stage of curing at $25^{\circ} \mathrm{C}$ for 2,7 , and 28 days and at $49^{\circ} \mathrm{C}$ for 2 days.

At the end of curing stage, the samples were extracted from the foil paper and wax, weighted and divided into two groups; first group oven dried at $60^{\circ} \mathrm{C}$ for 2 days before conducting the slake durability test (i.e following the procedure of ASTM D4644), the second 
group submerged for 2 days in water before conducting the slake durability test. After 2 days of drying (first group) or wetting (second group) ten samples of total weight about (400 to 600)gm slaked in the device of slaking for three cases of test duration time, first is 10 minutes (standard test duration time), the second and third cases are of 20 and 30 minutes respectively. Table (3) shows the research plan and the curing conditions (temperature and time)

Table (3) Research plan

\begin{tabular}{|c|c|c|c|c|c|c|c|}
\hline \multirow[t]{2}{*}{ Soil } & \multirow[t]{2}{*}{$\begin{array}{l}\text { Molding } \\
\text { moisture } \\
\text { content }\end{array}$} & \multicolumn{4}{|c|}{$\begin{array}{l}\text { Curing conditions for tests consist of } \\
\text { drying before slaking }\end{array}$} & \multicolumn{2}{|c|}{$\begin{array}{l}\text { Curing conditions for } \\
\text { tests consist of wetting } \\
\text { before slaking }\end{array}$} \\
\hline & & $\begin{array}{l}2 \text { days @ } \\
25^{\circ} \mathrm{C}\end{array}$ & $\begin{array}{l}7 \text { days } \\
\text { (a) } 25^{\circ} \mathrm{C}\end{array}$ & $\begin{array}{l}28 \text { days } \\
\text { @ } 25^{\circ} \mathrm{C}\end{array}$ & $\begin{array}{l}2 \text { days } \\
\text { @ } 49^{\circ} \mathrm{C}\end{array}$ & $\begin{array}{l}7 \text { days @ } \\
25^{\circ} \mathrm{C}\end{array}$ & $\begin{array}{l}28 \text { days @ } \\
25^{\circ} \mathrm{C}\end{array}$ \\
\hline \multirow[t]{3}{*}{ A } & dry & $\sqrt{ }$ & $\sqrt{ }$ & & $\sqrt{ }$ & & \\
\hline & omc & $\sqrt{ }$ & $\sqrt{ }$ & $\sqrt{ }$ & $\sqrt{ }$ & $\sqrt{ }$ & $\sqrt{ }$ \\
\hline & wet & $\sqrt{ }$ & $\sqrt{ }$ & & $\sqrt{ }$ & $\sqrt{ }$ & \\
\hline \multirow[t]{3}{*}{ B } & dry & & $\sqrt{ }$ & & & & \\
\hline & omc & $\sqrt{ }$ & $\sqrt{ }$ & $\sqrt{ }$ & $\sqrt{ }$ & $\sqrt{ }$ & $\sqrt{ }$ \\
\hline & wet & $\sqrt{ }$ & $\sqrt{ }$ & & $\sqrt{ }$ & $\sqrt{ }$ & \\
\hline
\end{tabular}

\section{4- Discussion And Results:}

\section{4-1- Effect of Molding Moisture Content:}

The weight loss according to the three selected moisture contents were calculated and presented in Fig.(3 to 6). Results show that the increase of molding moisture content causes reduction in the amount of weight loss for both soils for all cases of curing conditions. This behavior may be attributed to the soil structure at the dry side of compaction curve which is more flocculated than that of the other portions, so the amount lost at this side is larger.

The weight loss for soil A samples cured for 2 days at $25^{\circ} \mathrm{C}$ and compacted at moisture content (dry) and (omc) is about (29-43)\% and $(11-13) \%$ respectively, greater than the weight loss for samples compacted at moisture content (wet), as shown in the Fig.(3). While the extension of the curing time to 7 days leads to weight loss of $(57-85) \%$ and $(22-30) \%$ greater than the weight loss for samples compacted at moisture content (wet), as shown in the Fig.(4). While for soil A samples cured for 2 days at $49^{\circ} \mathrm{C}$ the weight loss for samples compacted at moisture

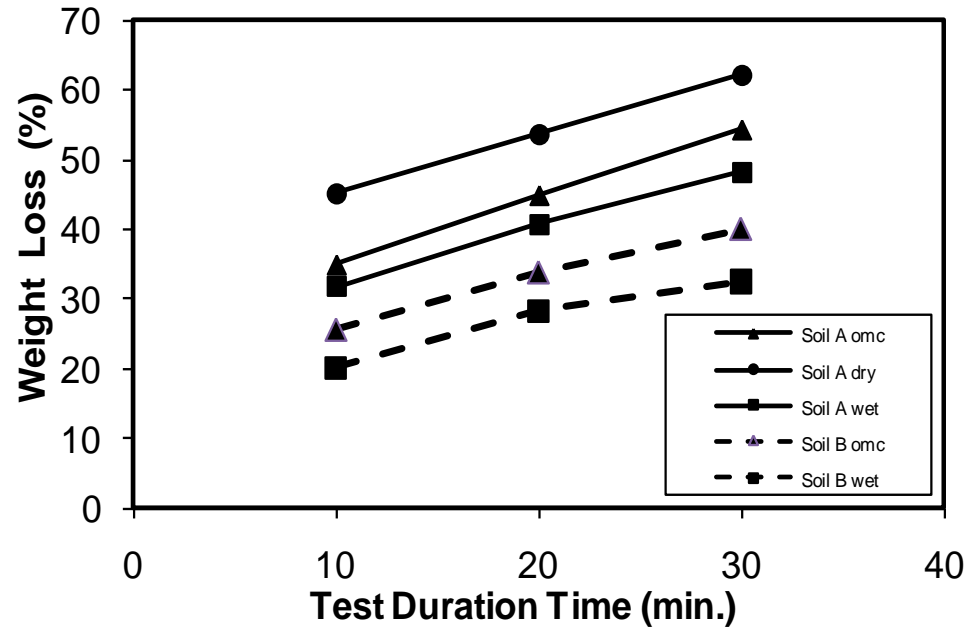

Fig.(3) Weight Loss For Soils A and B cured for 2days at $25^{\circ} \mathrm{C}$ content (dry) and (omc) is about (38-104)\% and (15-32)\% greater than the weight loss for samples compacted at moisture content (wet) for the curing conditions, as shown in the Fig.(5). 
The weight loss for soil $\mathrm{B}$ samples cured for 2 days at $25^{\circ} \mathrm{C}$ and compacted at moisture content (omc) is about (19-26)\% greater than the weight loss for samples compacted at moisture content (wet), as shown in the Fig.(3). While the extension of the curing time to 7 days makes the weight loss of samples compacted at moisture content (dry) and (omc) to be about (6190)\% and (20-34)\% respectively.

This is shown to be greater than the weight loss for samples compacted at moisture content (wet), as shown in the Fig.(4). In the other hand, for soil B samples cured for 2 days at $49^{\circ} \mathrm{C}$ the weight loss for samples compacted at moisture content (omc) is about (33-40)\% which is greater than the weight loss for samples compacted at moisture content (wet) for the curing conditions, as shown in the Fi

\section{4-2- Effect of Curing} Conditions:

Three curing durations were selected to show the effect of curing condition, (2, 7, and 28) days at curing temperature $\left(25^{\circ} \mathrm{C}\right)$, and 2 days curing at temperature of $\left(49^{\circ} \mathrm{C}\right)$.

Figs.(6) shows the results of loss in weight for soils A and B samples compacted at moisture content (omc), it could be noticed that, for soil A, with curing time 2 days as a reference, the weight loss decreased about (25-35\%) and about (49-52\%) as the curing time increased (from 2 to 7 days) and (from 2 to 28 days) respectively for all tests duration

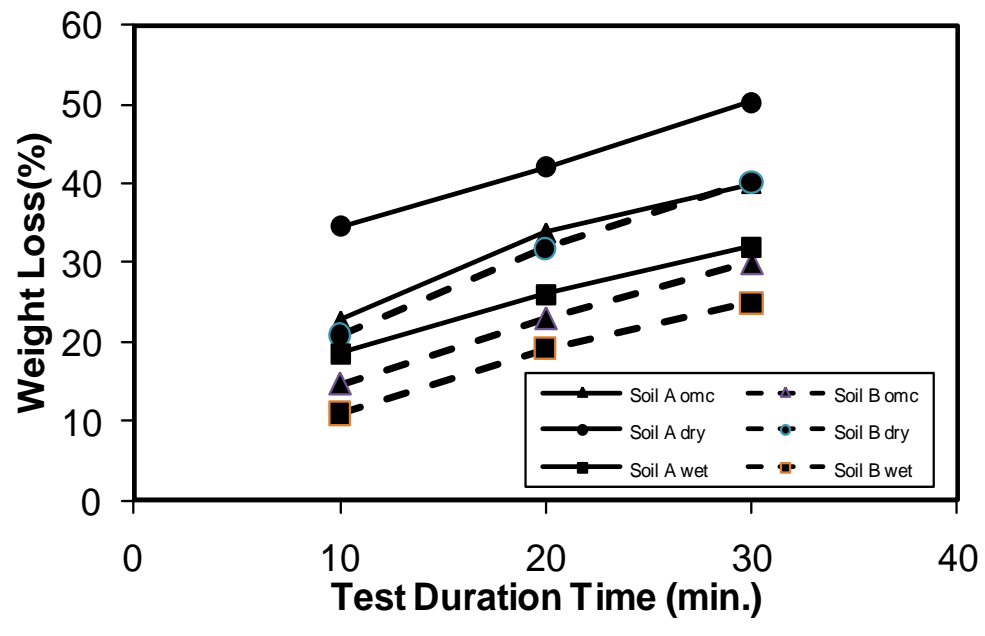

Fig(4) Weight Loss For Soils A and B cured for 7days at $25^{\circ} \mathrm{C}$

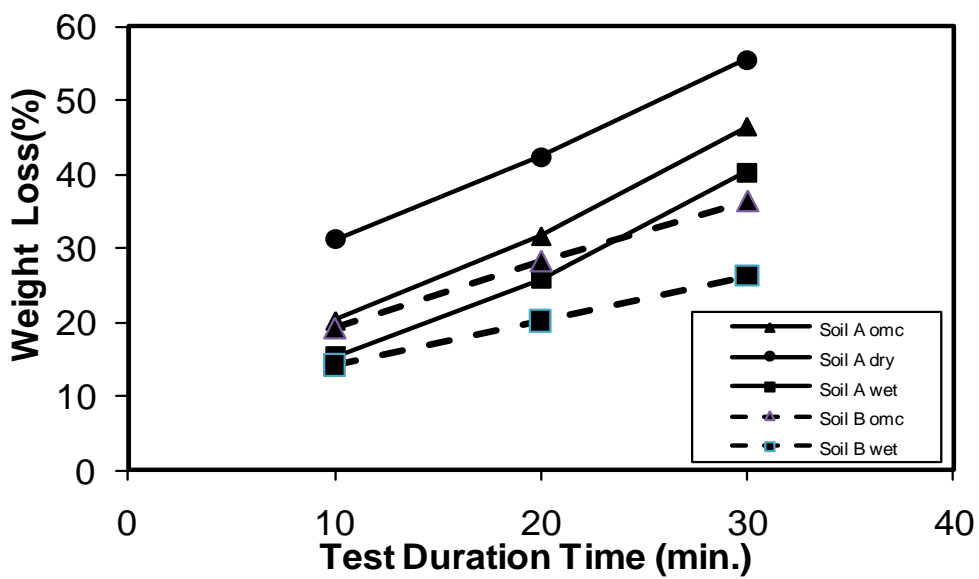

Fig(5) Weight Loss For Soils A andu B cred for 2days at $49^{\circ} \mathrm{C}$

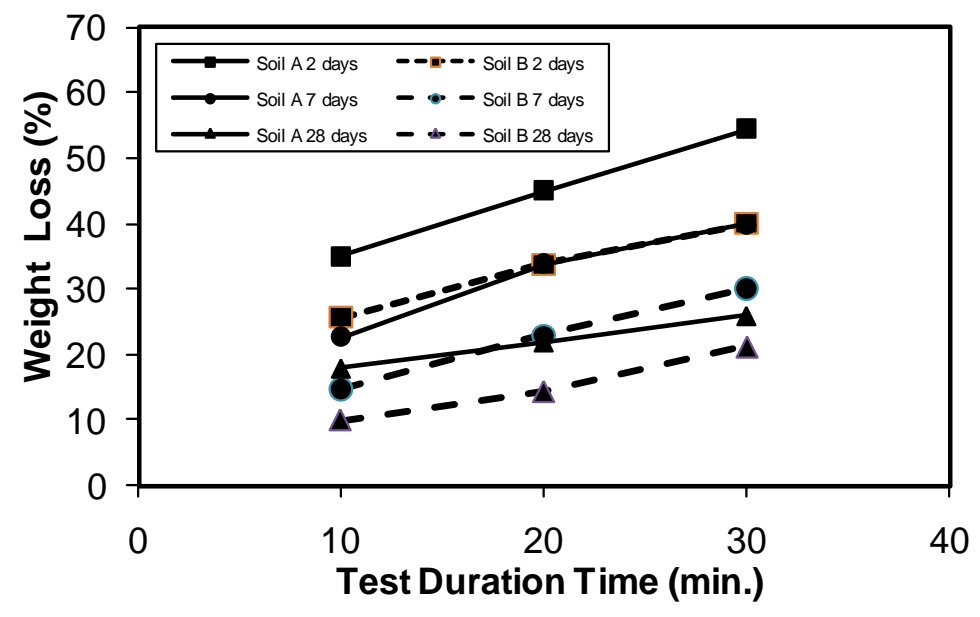

Fig.(6) Comparison of Weight Loss of Soils A And B cured For $2,7, \& 28$ days at $25^{\circ} \mathrm{C}$ 
times. The obtained results of soil B also showed that the weight loss decreased about (25$43 \%$ ) and about (47-61\%) as the curing time increased to 7 and 28 days respectively for all tests duration times as shown in Fig.(6).

The reduction in weight loss may be attributed to the pozzolanic reaction which increases the soil strength with the curing time[12].

The effect of increasing of the curing temperature can be obtained by comparing Fig.(3) and Fig.(5). From these figures it can be seen that, as the curing temperature increased the weight loss decreased. For soil $\mathrm{A}$ the reduction was about $(11-31) \%,(15-42) \%$, and $(17-52) \%$ for samples molded at moisture "dry", "omc", and "wet" respectively as the temperature increased from $25^{\circ} \mathrm{C}$ to $49^{\circ} \mathrm{C}$ for 2 days of curing.

For soil B the reduction was about $(9-15) \%$ and $(19-28) \%$ for samples molded at moisture "omc" and "wet" respectively as the temperature increased from $25^{\circ} \mathrm{C}$ to $49^{\circ} \mathrm{C}$ for 2 days of curing.

Soil A gives a higher weight loss than soil B by (5 to 39)\% depending on the curing and molding moisture content.

The weight loss for soil A samples compacted at omc and cured for 2 days at $49^{\circ} \mathrm{C}$ is $(20.23$, 31.64 , and 46.44) for test duration time (10, 20, and 30) minutes respectively, using these values in Fig.(7), it could be notice that, curing samples for 2 days at $49^{\circ} \mathrm{C}$ is

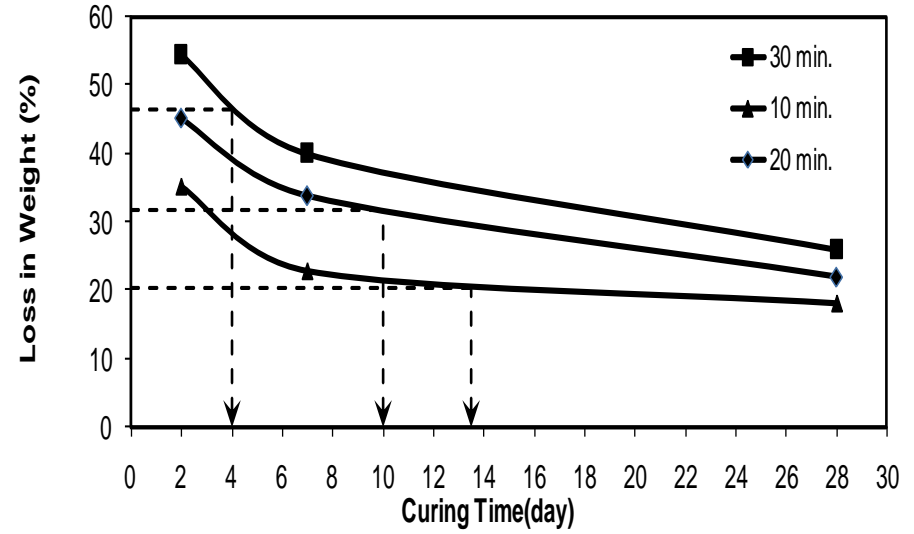

Fig.(7) Weight Loss With Curing Time For Soil A Cured at $25^{\circ}$

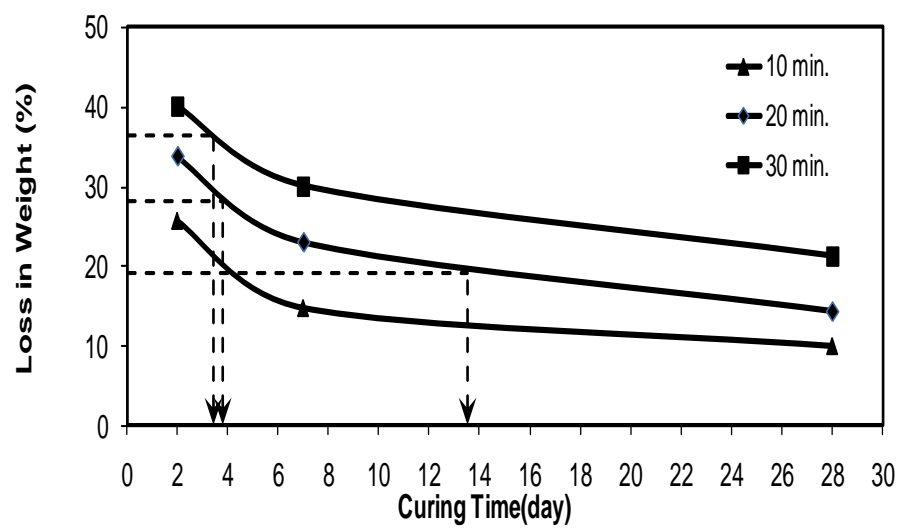

Fig.(8) Weight Loss With Curing Time For Soil B Cured at $25^{\circ} \mathrm{C}$ approximately equivalent in its effect to curing for (4-13.5) days at $25^{\circ} \mathrm{C}$, also for soil B samples compacted at omc and cured for 2 days at $49^{\circ} \mathrm{C}$, the weight loss is $(19.20,28.21$, and 36.29) for test duration time $(10,20$, and 30) minutes respectively, using these values in Fig.(8), it could be notice that curing samples for 2 days at $49^{\circ} \mathrm{C}$ is approximately equivalent to that cured for (3.4-13.5) days at $25^{\circ} \mathrm{C}$

\section{4-3- Effect of Test Duration:}

Weight loss during slaking time of 10 (standard time of ASTM D4644), 20, and 30 minutes was studied, results are presented in Figures (3 to 6) which showed that the weight loss approximately doubled when test duration time increased from 10 to 20 minutes. Increasing the test duration time from 10 to $30 \mathrm{~min}$. resulted in, approximately, triple the 
amount of weight loss. In other words a linear relationship between test duration time and weight loss was attained. So, increasing test duration time to more than 10 minutes provides no more information about the behavior of lime stabilized soils.

\section{4-4- Effect of Test Procedure:}

To study the effect of prewetting or drying before conducting slake durability test, two cases were studied; first case, similar to the standard procedure of rock slake durability test, where the samples are dried for $48 \mathrm{hrs}$ in $60^{\circ} \mathrm{C}$ then starting the slaking process. The second case is submerging (wetting) the samples for $48 \mathrm{hrs}$ then starting the slaking process. It is important to mention that submerging the samples causes increase in the degree of saturation up to (92 and 96)\% for soil A and B respectively.

The results are shown in the Figs.(9-11) for both soils. Pre-

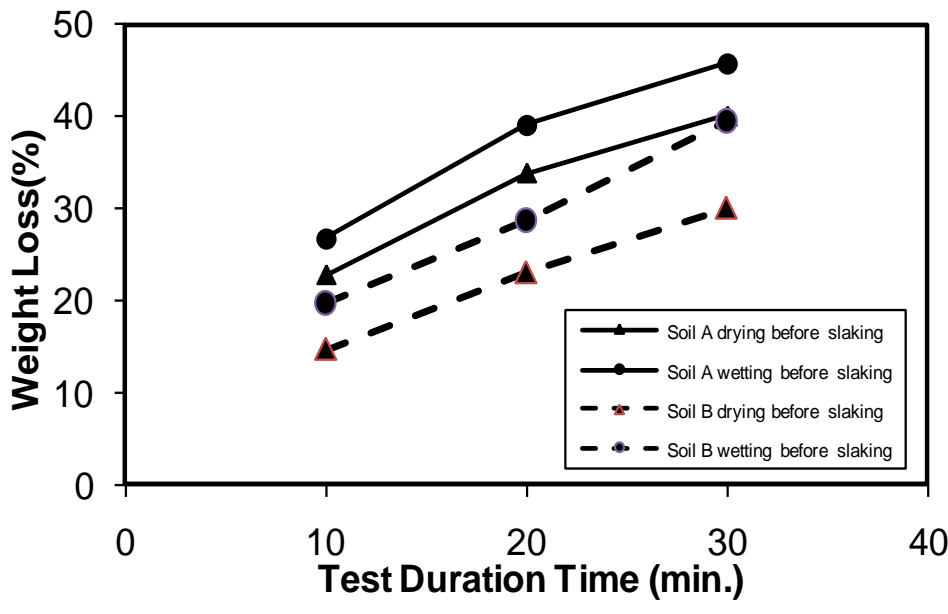

Fig.(9) Soils A and B Compacted at molding moisture content omc cured for 7 days at $25^{\circ} \mathrm{C}$ with different slaking procedure submerging the samples, causes increase in the amount of weight loss of about (8 to 13)\% for both soils comparing with the standard procedure of drying the samples before starting the test. The samples molded at moisture content "dry" and wetted before the slake test, were collapsed at the starting of the test due to weakening caused by wetting.

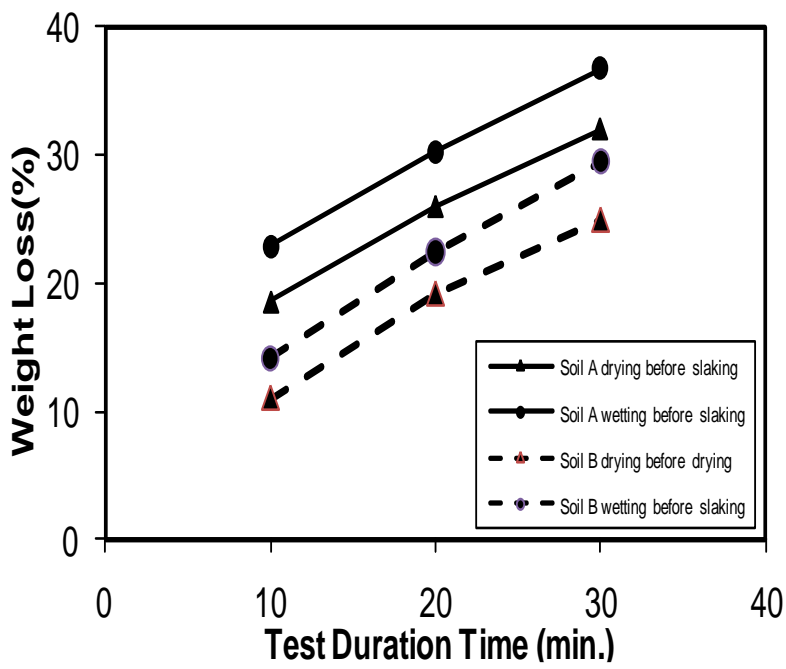

Fig.(10) Soils A and B Compacted at molding moisture content wet cured for 7 days at $25^{\circ} \mathrm{C}$ with different slaking procedure

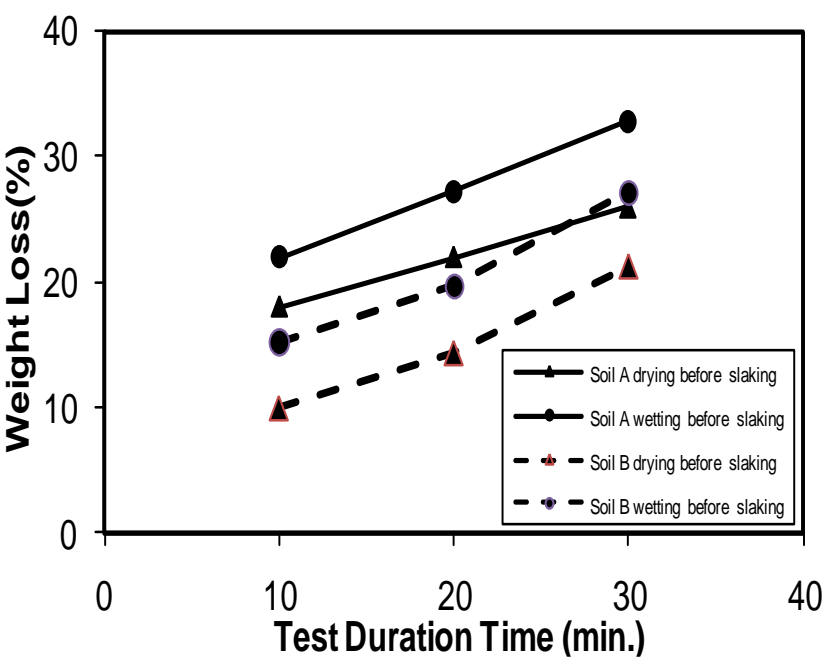

ig.(11) Soils A and B Compacted at molding moisture content omc cured for 28 days at $25^{\circ} \mathrm{C}$ with different slaking procedure 


\section{Conclusions:}

1. Durability of the gypseous soil A is lower than soil B, due to softening of the gypsum which acts as a binder of soil particles in the dry state.

2. Test duration time $10 \mathrm{~min}$. is adequate and is recommended for studying the durability of lime stabilized soils. Longer times just increase the amount of weight loss, and give no more or new information.

3. Curing for 2 days at $49^{\circ} \mathrm{C}$ approximately equal to (4-13.5) and (3.4-13.5) days at $25^{\circ} \mathrm{C}$ for soil A and $\mathrm{B}$ respectively.

4. The cured soil samples subjected to wetting then slaking give more weight loss than those subjected to drying before slaking. So, to obtain the maximum durability in the field, it is preferable that the stabilization process of soil should be conducted in a suitable warm temperature followed by dry season.

5. Soil samples compacted at molding moisture content in the dry side of compaction curve show a higher weight loss than samples compacted at optimum or wet side of compaction curve. While a lower weight loss was obtained with samples compacted at molding moisture content in the wet side of compaction curve.

\section{References:}

1- "CHEMICAL STABILIZATION DURABILITY" http://haroconsulting.com/fact_sheets/DURABILITY_OF_STABILIZED_SECTION.pdf

2- ASTM - Standards , Book of American Society for Testing and Material, section 4, 1998.

3- Humadi A. R. (1989) "A Study on strength and durability of Arbil soils stabilized with additives" M.Sc. Thesis, Civil Engineering Dep. University of Salah-Edeen.

4- Al-Rkaby, A. H. (2004) "Stabilization of Sub-Base Layers With High Gypsum Content Using Lime" M.Sc. Thesis, Civil Engineering Dep. University of Mosul (in Arabic).

5- Hussein, Yousif A. (2005) "Durability of lime stabilized gypseous soil" M.Sc. Thesis, Civil Engineering Dep. University of Mosul (in Arabic).

6- Rao, S. M. and Shivananda, P. (2001) "Swelling behavior of lime-stabilized specimens after multi-wetting and drying cycles" Workshop in clay Behavior ChemoMechanical Coupling from Nano-Structure to Engineering Application, Vol.2, Italy.

7- Mohammed, Rabi A. (2008) "Effect of Durability on the tensile strength of stabilized soils" M.Sc. Thesis, Civil Engineering Dep. University of Mosul (in Arabic).

8- Misira A. K. and Mathur R. (August 1988) "Micro level study on the mechanism and durability of lime stabilized soil" Indian Highways, pp. 17-35.

9- Atallah, Mofaq A. A. (2006) "Durability test by wetting /Drying cycles of lime stabilized gypseous soils under loading" M.Sc. Thesis, Civil Engineering Dep. University of Mosul (in Arabic).

10- Güney Y., Koyuncu, H. and Cetin, M. (2003) "Environmental effects on expansive soils" proceedings of the first international conference on Environmental research and assessment, Bucharest, Romania, pp.23-27.

11- Khattab, S. A. A. (2002) "Eude multi-echelles d'un sol plastique traite' a' la chaux" PhD Thesis, University of' Orleans, France.

12- Little, D.N. (1995), "Handbook for Stabilization of Pavement Sub-grades \& Base Courses with Lime", Kendall/Hunt Publishing Company, Iowa, USA, by National Lime Association. 